Published by the University of KwaZulu-Natal https://journals.ukzn.ac.za/index.php/JICBE

(C) Creative Commons With Attribution (CC-BY)

Journal of Inclusive cities and Built environment. Vol. 1 Issue 2

How to cite: Olanrewaju et al. 2021. Assessing The Inclusiveness of Housing Conditions in Ogbomoso Township, Nigeria. Journal of Inclusive cities and Built environment. Vol. 1 Issue 2, Pg 71-78.

\title{
ASSESSING THE INCLUSIVENESS OF HOUSING CONDITIONS IN OGBOMOSO TOWNSHIP, NIGERIA
}

\author{
By Olanrewaju, S.O., Siyaka A.A. and Audu, G.G.
}

Published 25th October 2021

\begin{abstract}
It is against the background of deficit in housing stock in Nigeria major cities and its associated exclusion that this study evaluates housing condition in Ogbomoso Township. This is with a view to proffering recommendations that will aid the achievement of sustainable and inclusive housing in the town, and other ones with similar socioeconomic characteristics. Assessed were the socioeconomic characteristics of residents, characteristics and condition of housing units, and impact of the identified condition on residents. The study utilized a multistage sampling approach to sample 150 buildings, and questionnaire administered to an adult resident in each of the sampled building. Data obtained were summarized using tables and percentages while analysis of variance was used to evaluate variation in the condition of housing units across political wards in the study area. The study discovered that about $44.7 \%$ of the residents have been living in their residences for less than 5 years, thus suggesting frequent change of residences by residents to adjust and readjust to various exclusion tendencies. Reasons for this include the perceived substandard nature of the housing units. It therefore, among others, recommends that inclusive development should be encouraged in the study area through enlightenment programmes, subsidization of building materials and policy interventions.
\end{abstract}

KEY WORDS Housing; Housing Condition; Sustainable Development, Inclusion

Olanrewaju, S.O - Department of Urban and Regional Planning, Kebbi State University of Science and Technology, Aliero, Nigeria Corresponding email and address: Olanrewajusamson9@gmail.com; +234 7038540456

Siyaka A.A. - Department of Urban and Regional Planning, Abubakar Tafawa Balewa University, Bauchi, Nigeria Audu, G.G. - Plateau State College of Health Technology, Zawan, Nigeria 


\section{INTRODUCTION}

The term housing can be traced to human quest for a place of abode. However, with events of time, this standpoint changed to great urge for comfort, sociability and satisfaction that emerged as its critical indicators. Nubi (2000) asserted that housing to most group of people still remain a shelter, but to others, it serves best as an indicator of standard of living and societal position. It is not a gainsay that vigorous and buoyant housing sector is an indication of a strong programme of national investment and is indeed the foundation of future economic growth and social development.

Yet among the greatest problems in the world is the problem of growth and development. Resulting from these is the challenge of balancing the rate of growth and development with the provision of basic necessities of life such as housing. Currently, and most especially in Africa, more than one billion people live indecent areas with lack of durable housing and adequate living space (Amnesty International, 2011). For instance, in Nigeria, even though there are no accurate data on the nation's housing stock, earlier studies and observations strongly suggest quantitative and qualitative housing problems across the country (Onibokun, 1983). Increasing high rent and scarcity maybe a pointer to the fact that there is a decrease in quantity and quality of housing stock in Nigeria major cities (Olawuni et al, 2007). As a result, good number of urban residents do not have access to good housing and its associated benefits. These have various health, social, physical and psychological consequences (Sclar et al, 2005). Unfortunately, the number communities of with poor and decaying housing units continuing to grow at an alarming rate, thus requiring both policy and research intervention (UN Habitat, 2010).

To address the escalating problem of housing in Nigeria, especially in major urban areas characterized with migration and poverty, administrators ranging from the National to the local, international organizations and other stakeholders have formulated numerous policies and introduced many housing interventions to promote access, dignity, equity, equality and inclusion. These include the Millennium Development Goals, Sustainable Development Goals, The New Urban Agenda, African Union Agenda 2063, National Housing Policy, Mortgage Housing in Nigeria. Despite these, housing challenge in major cities of the country, like other ones in SubSaharan Africa (SSA) remains prevalent (Davis, 2004). Factors accountable for this are lack of data, swindling political will, rapid informal urbanization and population explosion in Nigeria's cities. Therefore, despite the promissory nature of these initiatives, they have been unable to be translated to achieve inclusion.

Ogbomoso, a secondary city in Nigeria, is experiencing economic restructuring, resulting from the establishment of significant economic entities like Ladoke Akintola University of Technology, annex of Lautech Teaching Hospital, Bowen Teaching Hospital and other complementary institutions which have led to a decline in agricultural activities and an increase in her population. As at the year 2000, Ogbomoso had the population of 222,000 , but this currently stands at a skyrocketed value of 557,000 in the year 2021 (Macrotrends, 2021). This flood of immigration, observably, drives many physical and economic developments in an uneven pattern across the town. In response, housing stock in the town responds accordingly to this uneven pattern of physical and economic developments - thereby having a high tendency of promoting housing exclusion. This is, however, not sufficient to say until an investigation is made. It is against this background that this study assesses the inclusiveness of housing conditions in Ogbomoso town, this is with a view to proffering recommendations that will aid the achievement of inclusive housing in the town and other ones with similar characteristics.

\section{LITERATURE REVIEW}

Inclusiveness is multidimensional and comprised of spatial, social, environmental, economic, and political dimensions in which the characteristics of participation, equity, accessibility and sustainability are sometimes interwoven. Discussions and advocacy on inclusiveness, like other brands of cites such as smartism and equity, are developed to close the gaps created by socioeconomic systems and political administration of cities. These gaps, which include variation in wealth and opportunities affects choices, options and access - with urban poor at the receiving end. Housing, as one of human basic needs, is also influenced by these trio (of choices, options and access). Therefore, if not consciously included, urban poor have the tendencies of being alienated in city architecture - including housing services.

Housing encompasses all social services and utilities that make life meaningful and the environment habitable. The problems that affect housing in Nigeria are enormous and very complex. These problems, in Nigeria's cities, encompasses unavailability of housing units both in quality and the number available, which in turn has resulted into congested homes and communities, its associated pressure on infrastructural facilities and exclusion - particularly the vulnerable and urban poor. Another dimension to housing exclusion in Nigeria is the right to housing services which is strongly tied to the socioeconomic characteristics of residents - thereby jettisoning the concept of housing as a social system. The situation in the rural area is even worse where the quality of housing is very poor. Also, infrastructures like power, roads, water, drainage and every other constituent of housing are readily unavailable.

The provision of affordable housing in developing countries has been facing a number of challenges. These include high cost of building materials, low income and lack of access to land which have manifested low productivity and 
provision of poor quality yet expensive housing (Arimah, 2000, Olotuah 2009). The above stated problems are escalating each passing day due to several reasons, which include; absence of proper monitoring and evaluation of public housing policies and programmes, low capacity of public housing agencies and so on. As a result of these varying challenges, Nigeria's urban housing problems manifest in overcrowding, slum housing and the development of shanties in virtually every major Nigerian cities as the outcome of large concentration of people in inadequate housing unit whereby they exert unprecedented pressure on one another (Olotuah 2009).

The increasing pace of urbanization and the high tempo of rural-urban migration make housing problem in cities and towns very acute. Available evidence shows that many Nigerians do not have access to good shelter or descent homes (Sulyman, 1989, Aliu and Adebayo, 2010). In Nigeria, from the debut efforts of the Lagos Executive Development Board (LEDB) in 1928 to date, the challenges of public housing provision in the country have continue to lag behind the demand for housing, as almost $90 \%$ of the nation's housing stock is provided by the informal sector (UN-HABITAT, 2006). As a result, housing in Nigeria has been criticized for failing to generate tangible and sustainable housing production, distribution and acquisition mechanisms to meet increasing housing demand, particularly by low-income earners (Mba, 1992; Olotuah and Bobadoye, 2009). This situation requires assessment.

\section{STUDY AREA AND RESEARCH METHODOLOGY}

Ogbomoso Township is the core and administrative centre of Ogbomoso region. It comprises of two local government area viz Ogbomoso North and Ogbomoso South. Other local government areas in the region are Surulere, Oriire and Ogo-Oluwa. The town is located in the South-West geopolitical zone of Nigeria. It lies on latitude $80101 \mathrm{~N}$ and longitude $40101 \mathrm{E}$ of the globe. A derived savannah, Ogbomoso is about $105 \mathrm{~km}$ North-East of Ibadan, the capital of Oyo State, $58 \mathrm{~km}$ North-west of Osogbo, the capital of Osun State, $53 \mathrm{~km}$ South-west of Ilorin the capital of Kwara State and $57 \mathrm{~km}$ North-east of Oyo town. Ogbomoso's built up area has a total land area of about $164.48 \mathrm{~km} 2$.

The township started as an agricultural town and defense fortress which aided both its settlement and initial population growth. The town came to prominence and witnessed its major growth with the entrance of the Baptist missionaries in about 1907 which saw to the establishment of Baptist Medical Centre and Baptist School of Nursing (now Bowen University Teaching Hospital). These facilities not only aided the socioeconomic growth of Ogbomoso, it also plays a vital role in her population growth, urban expansion and housing demand. The subdivision of the town to two local government areas (i.e Ogbomoso North and Ogbomoso South Local Government Areas) in the year 1991 and establishment of Ladoke Akintola University of Technology led to the upgrade of the town to its full urban status. These developments led to a boom in the town's population which further increased the stress on her socio-environmental fabrics, including housing. It also opened the path for the emergence of various factors and indicators of housing exclusion such as reduced quality of housing, escalated prices, unbalanced supply and demand, reduction of open spaces, emergence of gated houses, and reduced right to services and city - a situation that this study investigated.

Primary data utilized for the study include socioeconomic characteristics of residents, housing characteristics and effect of such on residents which were obtained with the aid of questionnaire.

The sample frame of the study is Ogbomoso Township which consists of Ogbomoso North and Ogbomoso South Local Government Areas. To determine the number of questionnaire that were administered for the study, an inventory of the housing units by ward within the town was done and a total of 114, 658 buildings were identified in the town. Thereafter, a total of 150 buildings (representing a sample size of $0.13 \%$ ) were selected using random sampling. Data collected were subjected to both descriptive and inferential statistics. Descriptive statistics such as percentages were used to summarize variables like socio-economic characteristics of the respondents, while differences in housing characteristics across the study area was evaluated with the aid of Analysis of Variance. 


\section{Figure 1: Map of Oyo State Showing the Study Area}

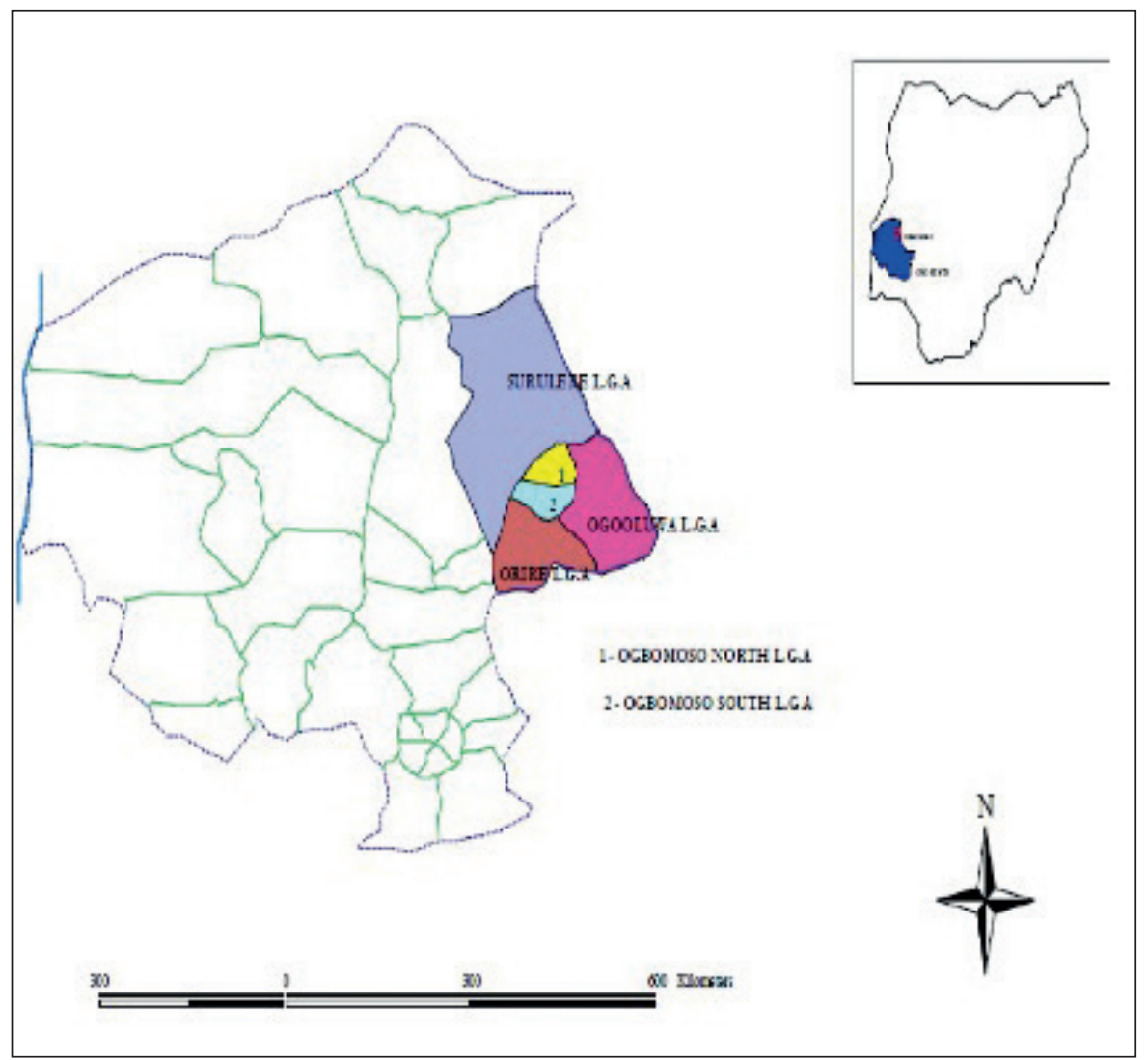

Source: Department of Urban and Regional Planning, LAUTECH, 2015

\section{RESULTS AND DISCUSSION}

The analysis from the questionnaires administered are presented and interpreted in this section. First, the socioeconomic characteristics of the respondents were examined, while housing type, characteristics and conditions were discussed consecutively.

\subsection{Socioeconomic Characteristics of Residents of Ogbomoso Township}

As summarized in Table 1, there are more males (50.7\%) in the study area compared to females. Also the town exhibits youthfulness, as those in this category accounts for $52.7 \%$. This notwithstanding, that about $4.0 \%$ of the population are 60 years and above, indicates that should there be instances of housing exclusion in the town, there are category of residents - in this case, the aged - that will be vulnerable to it. Hence, provision needs to be made to prevent housing exclusion of these vulnerable individuals. Also, the youthful characteristics of the town may indicate high mobility in all its dimension. In a way, it may signal the immigration of youths from nearby towns and villages - considering that the town is an institutional town. It can also inform high intra- movement within the town. Both cases present the tendencies for housing exclusion, For the former, and considering the usual unskilled nature of rural-urban immigrants, these youths may have a low financial strength. They are, therefore, vulnerable to exclusion from good houses in the town. In response, these set of individuals may continue to adjust and readjust to exclusion by moving from one area to the other in their quest for relatively satisfactory housing, and with increase in financial capacity.
Factors such as marital status, level of education and occupation influences needs, taste and perception to housing whereas income influences affordability of housing. Each of these factors also inform housing inclusion in non-socialist states like Nigeria. For instance, marital status influences mobility and choice of housing. Hence single individuals tend to be more mobile and can place less emphasis on housing condition in their quest for survival. However, married individuals, unless hampered with low income, are choosy. In the study area, a vast number of the respondents are single $(50.7 \%)$ while those that are married account for $40.0 \%$. Hence, there is a need to ensure that housing in the study area is inclusive to promote family life, civic and societal responsibility for both married individuals and single ones. Ogbomoso town is an elite town with about $62 \%$ of the respondents possessing tertiary education (Table 1) hence having a large population that will prefers housing units in good condition and top-notch facilities. Achieving this dream house is, however, subjectable to their affordability which is strongly connected to income.

Unfortunately, about $40 \%$ of the respondents are unemployed, while only $20.7 \%$ of them are engaged in the civil service. About $24 \%$ of the respondents are artisans, and not more than $10.6 \%$ of them are traders (Table 1). This saddening state of the respondents cannot be divorced from the current state of Nigerian's employment status, especially in the face of COVID-19 pandemic - that has forced a lot of the nation's populace from work. The unemployment rate of Nigeria as at March, 2021 is $33.1 \%$ and it is projected to increase, if not managed with desperate policies (Nigeria Bureau of Statistics, 2021). With these, not less than $46 \%$ of the respondents earn below $\mathrm{N} 18000$ (Nigeria's minimum wage), 28.7\% earn between \#18000-\#30000 while only $13.3 \%$ earn between \#30001 and \#60000 (Table 1). This has grave implications on the economic power and will of respondents, and by extension housing inclusiveness of respondents - 
as affordability of services is strongly affected. It also limits housing choices of respondent, thereby forcing them to live in poor housing units with associated environmental condition.

\section{Table 1: Socioeconomic Characteristics of Residents}

\begin{tabular}{|c|c|c|c|}
\hline Variables & & Frequency & Percentage \\
\hline \multirow[t]{3}{*}{ Gender } & Male & 76 & 50.7 \\
\hline & Female & 74 & 49.3 \\
\hline & Total & 150 & 100 \\
\hline \multirow[t]{5}{*}{ Age } & $18-30$ years & 79 & 52.7 \\
\hline & $31-45$ years & 41 & 27.3 \\
\hline & $46-60$ years & 24 & 16.0 \\
\hline & 61 years and above & 6 & 4.0 \\
\hline & Total & 150 & 100 \\
\hline \multirow[t]{5}{*}{ Education Level } & No formal Education & 22 & 14.7 \\
\hline & Primary Education & 2 & 1.3 \\
\hline & Secondary Education & 33 & 22.0 \\
\hline & Tertiary Education & 93 & 62.0 \\
\hline & Total & 150 & 100 \\
\hline \multirow[t]{6}{*}{ Occupation } & Trading & 16 & 10.6 \\
\hline & Civil Service & 31 & 20.7 \\
\hline & Artisan & 37 & 24.7 \\
\hline & Unemployed & 60 & 40.0 \\
\hline & Retired & 8 & 4.0 \\
\hline & Total & 150 & 100 \\
\hline \multirow[t]{5}{*}{ Marital Status } & Single & 76 & 50.7 \\
\hline & Married & 60 & 40.0 \\
\hline & Divorced & 8 & 5.3 \\
\hline & Widowed & 6 & 4.0 \\
\hline & Total & 150 & 100 \\
\hline \multirow[t]{6}{*}{ Monthly Income } & Below 18,000 & 69 & 47.9 \\
\hline & $18,000-30,000$ & 43 & 29.9 \\
\hline & $30,001-60,000$ & 20 & 13.9 \\
\hline & $60,001-90,000$ & 11 & 7.6 \\
\hline & Above 90,000 & 1 & 0.7 \\
\hline & Total & 150 & 100 \\
\hline
\end{tabular}

Source: Author's Field Work, (2021)

\subsection{Duration of Stay in Residences}

As summarized in Table 2, 44.7\% of the respondents have been living in their house for about $1-5$ years while about $26.7 \%$ have been residing in their house for almost 6-10 years and 8\% have been living in their building for nearly16 -20 years. This trend reveals that there are more new tenants compare to older tenants in buildings in the study area. Also, most of the respondents stays in their current houses for a short duration and leave such houses for a relatively comfortable one when things get better economically. 
Table 2: Duration and Reason for Stay

\begin{tabular}{|c|c|c|c|c|c|}
\hline \multirow{3}{*}{ Reason for stay } & \multicolumn{5}{|c|}{ How Long You Been Staying in this Area } \\
\hline & $1-5 y r s$ & $6-10 y r s$ & $11-15 y r$ & 16-20yrs above & Total \\
\hline & $\%$ & $\%$ & $\%$ & $\%$ & $\%$ \\
\hline Family ties & 6.7 & 4.0 & 2.0 & 1.1 & 14.9 \\
\hline Ownership status & 12.6 & 8.0 & 2.0 & 2.7 & 30.0 \\
\hline Low cost & 8.7 & 5.3 & 2.7 & 1.4 & 19.5 \\
\hline job opportunity & 4.7 & 2.7 & 1.3 & 0.8 & 10.3 \\
\hline All of the above & 8.0 & 4.7 & 2.0 & 1.3 & 17.3 \\
\hline None of the above & 4.0 & 2.0 & 0.6 & 0.7 & 0.8 \\
\hline Total & 44.7 & 26.7 & 12.6 & 8.0 & 100 \\
\hline
\end{tabular}

Source: Author's fieldwork (2021)

\subsection{Housing Condition and Characteristics}

Generally, houses in Ogbomoso township can be rated to be in good condition. This is as about $88 \%$ of them are built with concrete blocks while only $8.7 \%$ and $2.7 \%$ of them are respectively built with mud and stone. Of these houses, $78 \%$ have sound walls while only $12 \%$ are leaking and about $9 \%$ are sagging (Table 3 ). These condition may not be divorced from the relatively new nature of the houses in the town. This is as about $69 \%$ of these houses are constructed within the last 20 years. Good as this is, it also creates the gap of exclusion as some of these new buildings are built following modern design specifications - with gated fences, reduced common space, and isolated environmental characteristics. This, therefore, excludes other houses in the same neighborhoods from enjoying services in these new houses that can be beneficial to the community. Hence, residents in the same neighbourhood are exposed to different environmental condition based on their individual housing characteristics.

Analysis of Variance was used to assess variation in the condition of housing in the town. To achieve this, a variable "housing condition" was developed as a surrogate of wall, roof and floor condition. This surrogate variable "Housing Condition" was then subjected analysis of variance. The F-Test result reveals that, with $F=13.050$ and $p=0.000$, there is a statistically significant variation in housing characteristics across the 31 political wards in the study area (Table 4).

Table 3: Housing condition and Characteristics

\begin{tabular}{|l|l|l|l|}
\hline Variable & Categories & Frequency & Percentage (\%) \\
\hline \multirow{4}{*}{ Wall condition } & Sound & 118 & 78.7 \\
\cline { 2 - 4 } & Leaking & 18 & 12.0 \\
\cline { 2 - 4 } & Worn off/sagging & 14 & 9.3 \\
\cline { 2 - 4 } & Total & 150 & 100 \\
\hline \multirow{5}{*}{ Type of house } & Mud & 13 & 8.7 \\
\cline { 2 - 4 } & Concrete block & 133 & 88.7 \\
\cline { 2 - 4 } & Stone & 4 & 2.7 \\
\cline { 2 - 4 } & Total & 150 & 100 \\
\hline & Brazilian & 17 & 1.7 \\
\cline { 2 - 4 } & Flat/duplet & 88 & 58.7 \\
\cline { 2 - 4 } & Story building & 45 & 30.0 \\
\cline { 2 - 4 } & Total & 150 & 100 \\
\hline \multirow{5}{*}{ Ages of building } & Less than 20yrs & 104 & 69.3 \\
\cline { 2 - 4 } & $20-30 y r s$ & 24 & 16.0 \\
\cline { 2 - 4 } & $31-60$ & 19 & 12.7 \\
\cline { 2 - 3 } & $60 y r s$ above & 3 & 2.0 \\
\cline { 2 - 3 } & Total & 150 & 100 \\
\hline
\end{tabular}

Source: Author's fieldwork (2021) 
Table 4: Variation in Housing Characteristics across the Study Area

\begin{tabular}{|l|l|l|l|l|l|l|}
\hline & & Sum of square & D & Mean square & F & Significance \\
\hline \multirow{2}{*}{$\begin{array}{l}\text { Housing } \\
\text { Characteristics }\end{array}$} & Btw group & 217.62 & 31 & 7.020 & \multirow{2}{*}{13.050} & \multirow{2}{*}{0.000} \\
\cline { 2 - 6 } & Within groups & 79.086 & 147 & 0.538 & & \\
\cline { 2 - 6 } & Total & $\mathbf{2 9 6 . 7 0 6}$ & $\mathbf{1 7 8}$ & & & \\
\hline
\end{tabular}

Source: Author's fieldwork (2021)

\section{IMPLICATIONS OF HOUSING CONDITIONS ON ACHIEVEMENT OF INCLUSIVE CITIES AND BUILT ENVIRONMENTS}

This study has successfully examined the inclusiveness of housing conditions in Ogbomoso Township. The township, a secondary city in Nigeria can be used as a template for other cities in the country, and by extension Africa. From the study, it is deducible that housing in Nigeria's cities, especially secondary ones, are not inclusive. To what extent, is a scope that is not covered in this study and proffered for future research. Unfortunately, driven by worsening economy, residents are left with little or no choice. Factors for housing exclusion includes dwindling economic situation and transition of traditional settlements into urban areas with little or no planning interventions. This has led into the branding and rebranding of old houses in urban cores as well as emergence of alien-like houses rather than a regeneration of these areas and their environmental conditions. If this trend remains unchecked, the urban centres will continue to manifest all form of exclusion with its housing fabric torn across the lines of socio economic potentials of residents.

Despite these, there exists opportunities to explore for the achievement of housing inclusiveness in African cities. Historically, African settlements are established, constructed, managed and administered to be inclusive. Evidences of these include the provision of central places, open spaces and communal structures. These can be explored to encourage inclusive housing in modern cities. The return to central places have the tendency of bringing people of different social classes to engage. Also, design templates and city structures can be revaluated and positioned to encourage central places.

\section{RECOMMENDATION}

Based on the results discussed above, the following recommendations are proffered:

- Government should engage in urban renewal projects such as slum clearance, redevelopment and conservation, depending on the level and type of housing decay.

- $\quad$ Government at all levels are encouraged to grant soft loans to community based organizations and individual landlords through various schemes in order to assist with necessary renovation and modernized their building and the environment.

- Market price of building material should be controlled and subsidized by government to encourage people to build maintain their houses.

- Effective development control should be encouraged. This will aid in the controlling haphazard development of buildings in the area.

\section{CONCLUSION}

From the foregoing, it is evident that while there are variations in condition of housing units in Ogbomoso Township, Nigeria, and the place of socioeconomic underpinnings cannot be underestimated. 


\section{REFERENCES}

Aliu, I. \& Adebayo, A. 2010, 'Evaluating the Influence of Housing Quality on Urban Residents Wellbeing: The Case of Lagos, Nigeria', International Journal of Academic Research, vol. 2, no. 6, pp. 401-410.

Amnesty International, 2011. Urban Poverty and Health in Developing Countries: Population Reference

Bureau.

Arimah, B. 2000, 'Housing Sector Performance in Global Perspective: A Cross-City Investigation', Urban Studies, vol. 37, no. 13, pp. 2551-2579.

Davies, P. 2004, What is Policy Evaluation?, The Magenta Book. London.

Ibem, E. 2009, 'Community -Led Infrastructure Provision in Low-Income Urban Communities in Developing Countries: A Study on Ohafia, Nigeria', Cities, vol. 26, no. 3, pp. 125-132

Mba, H. 1992, The Dilemmas of Housing Programmes in Nigeria in $\mathrm{H}$. C. Mba, J.U.Ogbazi \& K. O. Efobi (Eds.) Principles and Practice of Urban and Regional Planning in Nigeria, Awka: Mekslink Publishers, Nigeria.

Nubi, T. 2000, 'Financing Urban Housing'. A paper delivered in a workshop Organized by the Nigerian Building and Road Research Institute (NBRRI), Abuja, Nigeria.

Olawuni, P. Adeyinka, S. \& Abegunde, A. 2007, 'Intra-Urban Variation in Housing Quality: The Nigerian Experience', Journal of Land Use and Development, vol. 3, no.1, pp. 69-78

Omole, F. 2001, Basic Issues in Housing Development, Femo Bless Publishers, Ondo.

Olotuah, A. 2009, 'The Nigerian National Housing Policy in Perspective: A Critical Analysis', Journal of Social Development in Africa, vol. 26, no. 2, pp.165-188.

Onibokun, 1983, Urban Housing in Nigeria. NISER, Nigeria.
Sclar, 2005, 'Homelessness and Housing Policy: A Game of Musical Chairs', American Journal of Public Health, vol. 80, no.9, pp. 1039-1040

Sulyman 1989, 'Introduction to Housing: Basic Concepts and Applications', Olad Publishers, Nigeria.

UN Habitat 2010, The Challenge of slums: Global Report on Human Settlement: London and Sterling.

UN-HABITAT 2006, Urban Secretariat \& Shelter Branch. Expert Group Meeting on Urban Indicators: Secure Tenure, Slums and Global Sample of Cities. Nairobi, Kenya. 